\title{
A INFLUÊNCIA E O CONTROLE ESTATAL NA CONSTRUÇÃO DO SISTEMA EDUCACIONAL
}

ZAMBONI, Fausto. Análise das circunstâncias distantes. In: A opção pelo Homeschooling: guia fácil para entender por que a educação domiciliar se tornou uma necessidade urgente em nossa época. Campinas, Sáo Paulo: Kirion, 2020. p. 19-22.

Douglas Manoel Antonio de Abreu Pestana dos Santos

Universidade Ibirapuera, SP, Brasil. E-mail: douglasabreupestana@usp.br

\section{Alexandre Dijan Coqui}

Secretaria Municipal de Educação do Município de Jacaraci, BA, Brasil. E-mail: coqui.kok@hotmail. com

To livro "A opção pelo Homeschooling", Fausto Zamboni, discorre a partir da realidade 1 do ensino no Brasil para orientar seus estudos sobre a construção do ensino domiciliar e todas as questóes que permeiam os desafios na nossa realidade educacional. Discute sobre as questôes relacionadas ao sistema de ensino atual e a descrença na educação oferecida pelas instituiçóes aos estudantes e sua formação social, crítica, moral e ética e, por outro lado, os desmitifica os mitos sobre o homeschooling, no que concerne a socialização das crianças e adolescentes e seu desempenho, tanto acadêmico, quanto profissional.

Ao discutir sobre a educação em casa, dois pontos surgem: Os moldes educacionais no Brasil comportariam a aprovação legal da educação domiciliar com uma cultura tão diversificada? $\mathrm{Ou}$, vivemos exclusivamente um imperialismo cultural $^{1}$ que definem nossos papéis sociais e o ensino formal com seu currículo demarcado é a fonte de sustentação do poder e nos traça uma linha histórica de submissão a um controle social e econômico. A educaçáo domiciliar não quebraria essa hegemonia?

As interrogaçóes são respondidas ao longo da obra, no entanto, elegeu-se o capítulo II intitulado, Análise das circunstâncias distantes, para analisarmos o passado e compreendermos o presente. $\mathrm{O}$ autor chama ou interpela o interlocutor a pensar em um tripé que permeia a educação no Brasil: $\mathrm{O}$ descaso e a falta de prioridade na gestão da educação; falta de política efetiva com intuito real de resolver os problemas; ou a deficiência na estrutura do sistema educativo. São pontos fundamentais para uma análise sobre a opção pelo ensino domiciliar crescente no país. Para entender esses pontos, o capítulo, retoma a história da construção do sistema educacional para a compreensão do ensino hoje no Brasil.

Nesse capítulo o autor traça a formatação do ensino obrigatório como fonte de poder. A partir do momento da implantação de uma educação compulsória modificando as relaçóes entre

1 Para entender melhor esse assunto no texto Sobre as artimanhas da razão imperialista, In: Escritos de Educação, Pierre Bourdieu. Petrópolis, RJ: Vozes, 2014. 
estudante e professor, está além da obrigatoriedade para o desenvolvimento intelectual do aluno e a equidade no acesso e permanência, mas na manipulação do indivíduo pelo poder do estado.

Zamboni leva-nos as circunstâncias distantes para atingir seu objetivo de apontar as falhas na construção do sistema educacional em diversos contextos. Na França, em plena Revolução francesa, a necessidade de mudança é direcionada nas crianças por serem mais influenciáveis, assim, a médio e longo prazo a resposta é automática, mudar hábitos e pensamentos utilizando a educação como instrumento de mudança - entende-se aqui mudança como ato de influenciar os outros para o bem de um grupo especifico - não para o desenvolvimento crítico do indivíduo. Dessa maneira, os antigos valores políticos e religiosos são extirpados juntos com aqueles que não aderem ao novo contexto revolucionário.

$\mathrm{Na}$ Prússia, temos o controle estatal. Esse sistema é adotado por regimes como o nazismo, o fascismo e o comunismo, como fonte de controle do poder. O Estado possui a autoridade para controlar a formação educacional da população e, por consequência, na formação dos indivíduos dentro de um regime autoritário e, consequentemente, na formação do homem e sua submissão e domínio do estado sobre a vontade do povo.

Nos Estado Unidos, a tentativa de filósofos e educadores para utilizarem os moldes prussianos culminou em resistência. É interessante a concepção de Horace Mann "os pais entregam 'reféns', a 'causa sagrada da educação'”. A partir da Revolução Industrial, a mão-deobra é fator determinante na formação dos indivíduos. Observa-se no pensamento de Ellwood Cubberley (p.21), "Nossas escolas são fábricas onde o produto bruto (a criança) é plasmado e modelado". No entanto, esse pensamento, posteriormente, foi considerado um proselitismo tanto aos professores, como aos alunos.

Tal enfoque na educação obrigatória e nos moldes que favoreçam o sistema político e econômico, nas discussões feitas pelo autor, esboça a ideia de técnicas de manipulação psicológica, não sendo coautor de teorias da conspiração, mas de técnicas de submissão à autoridade e do conformismo, apoiadas no behaviorismo e na psicologia do engajamento ${ }^{2}$. Assim, as reformas educacionais estão pautadas no controle da produçáo, no crescimento populacional e nos fluxos migratórios, (p. 21), no entanto, o autor destaca que apenas esse controle náo satisfaria a demanda econômica e social, mas a gestão da própria mentalidade do povo. "A alteração e homogeneização de todo o tecido social, no mundo inteiro" (p.22), é impulsionado pelo controle da vida econômica, social e política, para tanto, a religião é fator fundamental como instrumento de manutençáo dessa nova ordem, caso seja adaptada aos moldes vigentes.

Esse processo de domínio social é visto por alguns filósofos como Russell que diante a ameaça de uma guerra nuclear o governo possa manipular a mentalidade do povo para pensar o que se deseja e como a necessidade estatal exigir. Ou seja, se o governo definir que a neve é preta, ela será preta para a população - conformismo.

Para o autor, a retrospectiva histórica no sistema educacional está distante da educação como desenvolvimento da inteligência (p. 22). A relação da obra de Fausto Zamboni e a obra de Zygmunt Bauman, Sobre educação e juventude ${ }^{3}$, possui relativa semelhança ao discutir sobre

\footnotetext{
Essas ideias estão explicadas na obra Maquiavel Pedagogo, Pascal Bernardin, Campinas, Vide Editorial, 2012. Para aprofundar é interessante conhecer a obra de Zygmunt BAUMAN, SOBRE EDUCAÇÃO E JUVENTUDE: CONVERSAS COM RICCARDO MAZZEO. RIO DE JANEIRO: ZAHAR.
} 
a indústria do consumo na exploração dos jovens e utilizando-se de sua fragilidade nas relaçóes sociais que são ampliadas por uma educação que cede ao mercado capitalista e não corroboram com uma formação social/crítica.

O autor conclui o capítulo apresentando os altos investimentos em transportes, informática e equipamentos militares e a educaçáo está longe de receber investimentos públicos e, principalmente, o ensino público está cada vez mais abandonado, distanciando da evolução que o mundo vem passando. Cresce os investimentos tecnológicos e falta tecnologia nas escolas: um paradoxo abissal.

Percorremos um caminho mais atual e possível de assistirmos a esses obstáculos. Vivese um período pandêmico: ou a suspensão das aulas, ou o crescimento do número de vítimas do Covid-19, decisóes que dividem opinióes. No entanto, a falta de tecnologia nas escolas públicas tornou-se visível, mesmo alguns estados ou municípios nadando contra a correnteza e elaborando estratégias possíveis para dar continuidade ao ensino, os desníveis sociais superam quaisquer tentativas de nivelar o conhecimento para todos.

É claro a manipulação político-econômica que afeta a população, principalmente, as menos favorecidas, contudo, a possibilidade de uma educação domiciliar existe, apenas com ajustes e investimentos públicos podem modificar o painel desesperador que muitos estão vivendo.

O texto é muito claro e cria uma leitura interessante abordando uma análise das circunstâncias distantes que afetam nossa realidade educacional e encerra de forma memorável "na verdade, o investimento foi na engenharia social por meio da educação, e nesse sentido os resultados são exatamente os esperados". Em plena pandemia e no caos que o mundo enfrenta, onde a mudança não é necessária, mas imprescindível, estamos colhendo exatamente os frutos que o poder político, social e econômico deseja saborear. 